\title{
A Mortgage Futures Market: Its Development, Uses, Benefits, and Costs
}

\author{
NEIL A. STEVENS
}

$\mathrm{N}$ inherent risk associated with dealings in commodities is the possibility of financial losses resulting from unexpected changes in the price of the commodity. One mechanism for reducing such risks is a futures market. Last fall a futures market in mortgages began operations on the Chicago Board of Trade. ${ }^{1}$ In view of the volatility of mortgage interest rates in recent years, this new futures market will likely be useful to some mortgage market participants in reducing their risks from unexpected interest rate novements.

In principle, this mortgage futures market operates in the same way as the traditional commodity futures markets, In this new market, contracts based on GNMA pass-through securities are traded rather than contracts based on commodities, such as wheat, corn, or silver. This article examines the underlying conditions leading to the development of this market, the uses it can offer to some mortgage market participants, and the benefits and costs of such a market.

Note: Material particularly helpful in the preparation of this article include "Hedging in GNMA Mortgage Interest Rate Futures," Chicago Board of Trade (November 1975), and Richard L. Sandor, "Trading Mortgage Interest Rate Fntures," Federal Home Loan Bank Board Journal (September $1975)$, pp. $2-9$.

tPrice quotes for this market are now published daily in the commodity section of the Wall Street Joturnal.

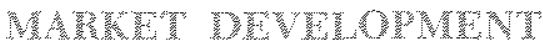

Futures contracts are standardized agreements to make or take delivery of a specified amount of a commodity at some future date. ${ }^{2}$ Contracts specify the commodity, its exact grade and quantity, the maturity date of the contract, details concerning delivery, and a number of other technical specifications. Prices of these contracts are determined by trading activity on organized exchanges. In well-functioning futures markets, contracts are seldom allowed to mature; that is, delivery of the commodity is not usually made or taken. A futures market position can be offset before the maturity date of the contract by simply executing an opposite buy or sell transaction.

Commodities traded on futures markets must be well defined; thus the chief problem in the development of a mortgage futures market was finding a suitable trading unit of uniform quality. Mortgage documents are not uniform nor does there exist a widely accepted grading system for standardizing mortgages. Mortgage markets have traditionally been localized, and have only recently become national

2 In general, a futures contract differs from a forward contract in that the forward contract is not negotiable, the terms are not standardized, and delivery of the commodity is expected anless otherwise agreed upon by the parties involved in the transaction. 


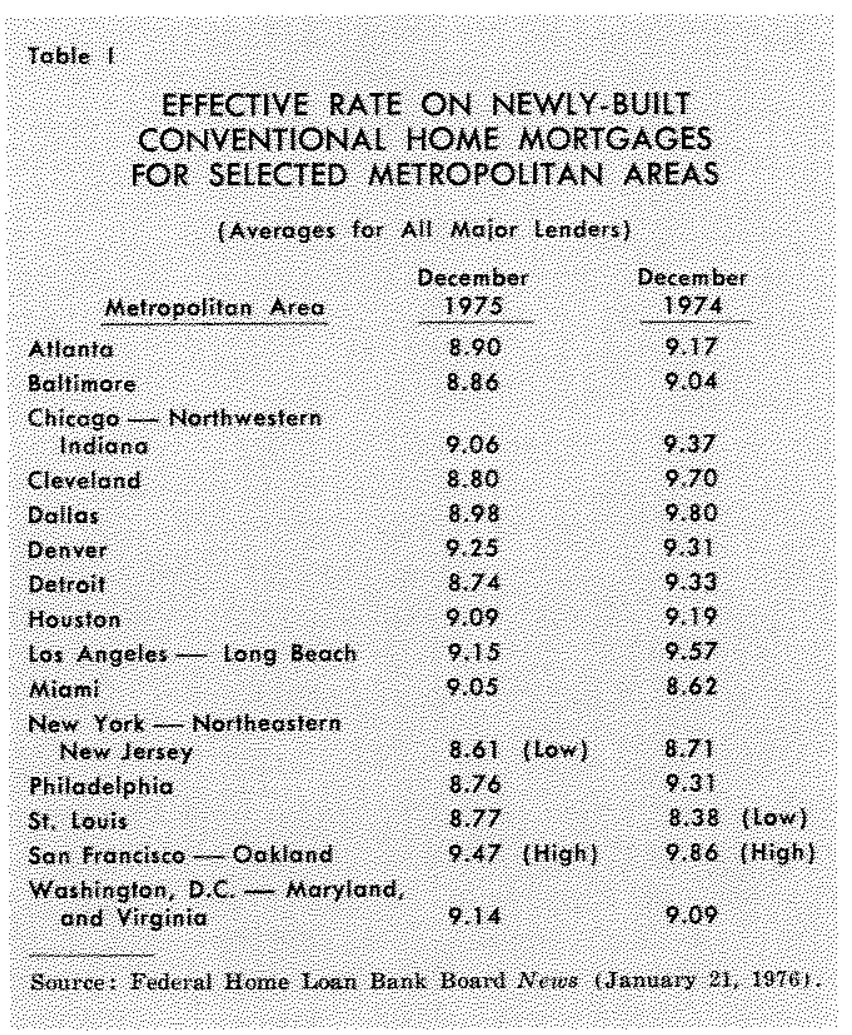

in character. Consequently, effective interest rates on conventional mortgages vary substantially among cities. $^{3}$ For example, according to a survey by the Federal Home Loan Bank Board, the effective rate on conventional mortgages for newly-built homes in December 1975 varied from a low of 8.61 percent in the New York City area to 9.47 percent in the San Francisco Bay area (see Table 1). Thus a futures contract based on conventional-type mortgages did not appear feasible in view of the diversity of these mortgages.

Two agencies have been given primary responsibility for improving the liquidity of mortgages. One, the Federal National Mortgage Association (FNMA and known in the trade as Fannie Mae) is a Govemmentsponsored corporation owned by private stockholders, but regulated by the Department of Housing and Urban Development." Operations of FNMA are aimed at providing liquidity for mortgages insured by the Federal Housing Administration and Farmers Home Administration, mortgages guaranteed by the Administration of Veterans Affairs, and conventional mortgages. It performs this function by making purchase commitments or purchasing and selling such mortgages. Another agency, the Federal Home Loan

TConventional loans usually refer to mortgages made by private lenders without Govermment insirance or guarantees. 4Contributions to FNMA capital stock are required for most buyers and sellers using the FNMA mortgage market.
Mortgage Corporation (FHLMC) whose capital stock is issued only to the twelve Federal Home Loan Banks, is authorized to purchase and sell residential mortgages. The primary purpose is to assist in the development of secondary markets for conventional mortgages. ${ }^{a}$

In addition to these Government-sponsored agencies, the Government National Mortgage Association (GNMA and known in the trade as Ginnie Mae), a Govemment-owned corporation under the Department of Housing and Urban Development, has among its operations the pass-through securities program. Under this program Ginnie Mae guarantees the timely payment of principal and interest on GNMA passthrough certificates. Such certificates are issued by private mortgage lenders against specified pools of mortgages insured by the Federal Housing Administration or guaranteed by the Administration of Veteran Affairs. Stated maturities on modified passthrough certificates are equal to those on the underlying mortgages (usually 30 years) and the minimum denomination of certificates is $\$ 25,000$. Holders of these certificates receive regular monthly interest and principal payments as well as any prepayments of principal. Ginnie Mae guaranteed $\$ 4.8$ billion of these securities in 1974 and another $\$ 7.4$ billion in 1975 .

A well-functioning secondary market for these securities currently exists among security brokers. Thus, the developers of the mortgage futures market viewed GNMA modified pass-through certificates as a suitable unit for basing mortgage futures contracts. As presently traded on the Chicago Board of Trade, the mortgage futures contract is specified as a GNMA modified pass-through certificate with a principal balance of $\$ 100,000$ and a stated interest rate of 8 percent. GNMA pass-through certificates bearing other yields can be used for delivery, providing they yield an equivalent 8 percent when calculated at par and under the assumption of a 30 -year certificate prepaid in the twelfth year. Prices of the GNMA futures contracts are quoted as a percentage of par; when market interest rates rise, the price of the futures contract falls and vice versa.

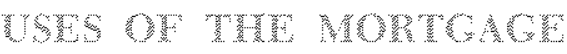

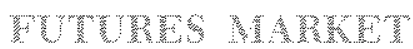

The primary functions performed by residential mortgage lenders are origination of loans, interim and

\footnotetext{
5Both FNMA and FHLMC are authorized to raise funds to purchase mortgages by issuing various types of securities in the capital market.
} 
short-term financing, and permanent financing. These functions may be carried out by the same firm or by different firms. The major institutions which perform these functions, and thus some of the potential users of the mortgage futures market, include savings and loan associations, mutual savings banks, commercial banks, insurance companies, and mortgage banks. Mortgage banks perform primarily the function of loan origination by making initial contact with the builder and home buyer, arranging short-term financing for construction, and finding a permanent buyer of the mortgages originated. Savings and loan associations and mutual savings banks, as well as commercial banks, often perform all three functions, while insurance companies, trust funds, and pension funds most often perform the role of permanent investor.

Various opportunities arise for the use of a mortgage futures market as a hedging device when these participants in the mortgage market carry out the origination and permanent financing functions. ${ }^{.}$In essence hedging is for the purpose of protecting a temporarily uncovered cash market position, either expected or existing, from price changes. ${ }^{\top}$ Hedging is carried out by temporarily taking an equal and opposite position in the futures market from that taken in the cash market, that is, buy in one and sell in the other. The futures market position should be cancelled when the cash transactions have been completed so that there is no longer an uncovered position.

Two basic types of hedges are possible - a sell hedge and a buy hedge. The sell hedge (sell futures) can be used to temporarily protect a commitment to buy mortgages or an existing inventory of mortgages held. A buy hedge (buy futures) can be used to temporarily protect a commitment to sell mortgages or fix the price of an expected purchase of mortgages. In addition to these hedging possibilities, the futures market can be used to undertake speculative actions.

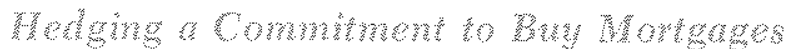

The use of commitments in the mortgage lending process gives rise to one use of a mortgage futures

\footnotetext{
"Since interim and short-rem loans often reflect short-term interest rate movements and yields on GNMA certificates reflect long-term interest rate movements, the GNMA futures market cannot be used to effectively hedge short-tern financing operations. Such short-term loar commitments may be more effectively hedged in the new Treasury bill futures market. Federal-related agencies that buy and sell mortgages may also use this futures market to reduce their risks.

${ }^{7}$ An uncovered position is one which is subject to price level risk, that is, a position where changes in interest rates, subsequent to taking the cash position, leads to either financial losses or gains.
}

market. ${ }^{8}$ When commitments are made to builders and homebtyers at fixed interest rates, subsequent changes in mortgage interest rates can result in a substantial financial gain or loss to the lender.

To give some idea of the amount of this risk, commitments outstanding at all savings and loan associations on July 31,1975 , amounted to $\$ 16.1$ billion, while yields on 8 percent Ginnie Mae securities in 1975 ranged from a low of 8.02 percent on February 12 to a high of 9.11 pereent on September 17 . With this range in yields, one GNMA contract $(\$ 100,000)$ would change approximately $\$ 7,500$ in value. The magnitude of these commitments and the possible fluctuations in mortgage interest rates can lead to considerable uncertainty in profits, especially in the short run, and therefore give impetus to the use of a mortgage futures market.

Suppose, for example, a savings and loan association makes arrangements to finance new housing construction and makes a commitment to finance the permanent loans at a given rate. The association expects to form a mortgage pool from the mortgages obtained and sell GNMA securities to investors. The commitments are made at the current market rate; however, should interest rates increase before the GNMA securities are sold to investors, the savings and loan association would have to sell the mortgages at a discount, thereby suffering a financial loss.

The GNMA mortgage futures market provides a mechanism for the savings and loan association to protect loan origination and servicing profits from interest rate movements. For an illustration of how such an interest rate hedge could be carried out, suppose that in January a savings and loan association makes $\$ 1$ million in permanent financing commitments to be consummated by June at $8 \frac{1}{2}$ percent, the going market yield of Ginnie Mae 8's at the time. ${ }^{9}$ The institution plans to form a pool of mortgages and issue GNMA pass-through securities to be sold to other investors rather than hold the mortgages in their own portfolio. If the savings and loan association decides to protect these cash market transactions from interest rate movements, it will sell 10 June GNMA futures contracts $(\$ 100,000$ each) at the time the commitments are made. For simplicity, assume that the

\footnotetext{
SCommitments as used here are defned as promises to buy or sell mortgages at a fixed price for future delivery, that is, forward contracts. Such commitments are considered here as a cash-type transaction. Also see footnote 2.

"The term "Ginnie Mae 8's" refers to GNMA pass-through certificates with a stated interest rate of 8 percent.
} 


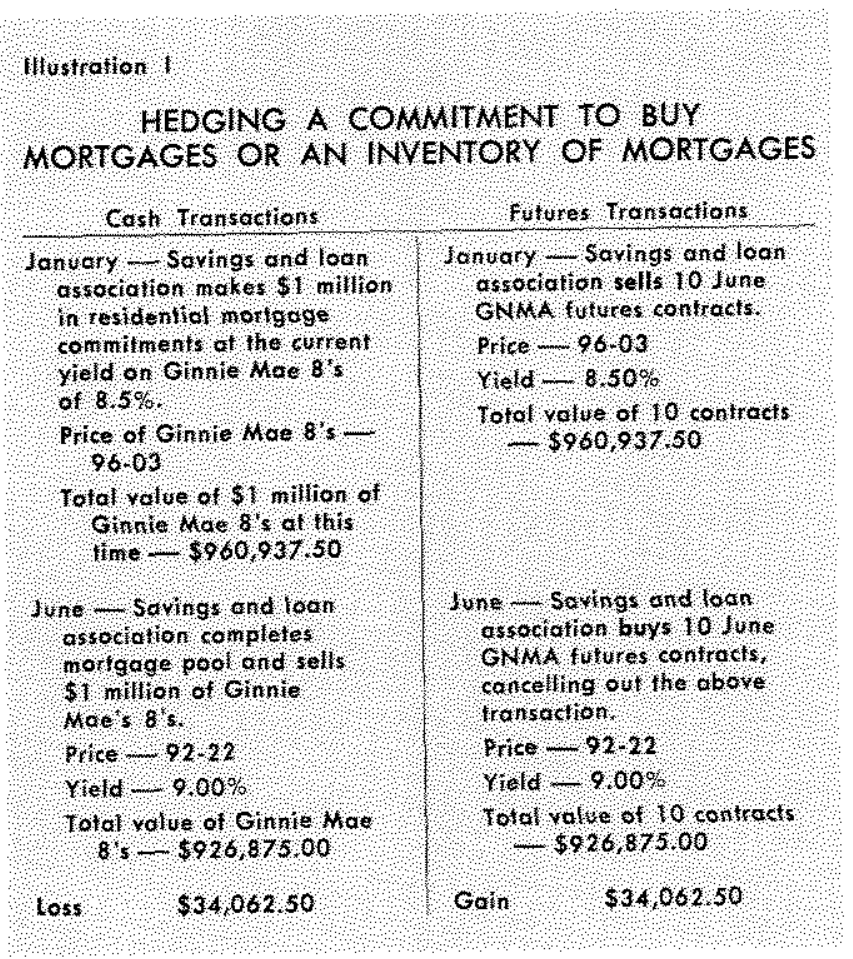

GNMA futures contract is priced at $96-03$, or a yield of 8.5 percent. ${ }^{10}$

Assume interest rates have risen by June, so the $\$ 1$ million of Ginnie Mae 8 s are sold to investor's at a price of $92-22$, a yield of 9 percent. GNMA futures prices will have also fallen (yields risen) reffecting the changed market conditions, and should approximately equal the price of the 8 percent Ginnie Mae securities sold to private investors in the cash market.1" The savings and loan association completes the hedge at the time the GNMA certificates are sold to investors by buying 10 June contracts, thereby offsetting the futures position taken earlier. From Illustration $\mathrm{I}$, the cash transactions alone resulted in a loss of $\$ 34,000$ to the savings and loan association while the futures tronsictions alone resulted in a gain of $\$ 34,000$. Thus, the firm has successfully hedged its commitments from increases in interest rates.

tog6-03 is read 96 and $3 / 32.93-03$ is equivalent to a yield of 8.5 percent assuming a 30 -year maturity and prepaid in the twelfth year.

11 In practice, the futures price and the cash price for GNMA fotures will differ somewhat depending on market conditions. In the delivery month of a contract, however, interest rates in both the GNMA cash market and the GNMA futures rataket should nomally be very close. If the cash price is significantly above the futures price, those who bought futures contracts will take delivery and make a profit by selling in the cash market, thus bringing pressure for the gap to narrow between the two markets. If, on the other haud, the futures price is significantly above the cash price, a profit can be made by buying mortgages in the cash market, selling fitures, and making delivery.
If interest rates had fallen during the January-June period, the opposite situation would occur in each market. The cash transaction would result in a financial gain to the lender while the futures transactions would result in a loss. On balance, however, the gains and losses should approximately offset each other, thus preserving the profit from origination and servicing of the mortgage.

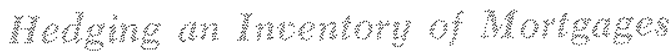

Originators of mortgages, especially mortgage banks, often make commitments simultaneously to both the investor and the borrower (builder or homeowner) at a specified rate, which effectively hedges the transaction. In other cases the originator may temporarily hold an inventory of mortgages without an agreed upon price. I2 If the loan originator follows the hedging procedure similar to that outlined in Illustration I, the GNMA futures market can be used as a means for avoiding large losses while the mortgages are held in inventory. These mortgages may be either Federally insured or conventional. The assumption necessary for a successful hedge, however, is that the price of the mortgages agreed upon between the originator and investor move in step with price movements in the GNMA futures market. This could be assured by agreeing beforehand that the price of the mortgages be pegged to movements in Ginnie Mae prices.

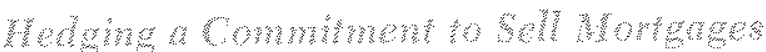

A Ioan originator might have occasion to make commitments to sell mortgages to an investor at a specific price before all the mortgages have been originated. A loan originator, such as a mortgage banker, would nomally avoid such situations for he bears the risks that market rates will decline, causing him to buy the mortgages at a higher price than expected. To protect himself in this situation, the bank can buy futures contracts at the time he makes the commitment to sell mortgages to the institutional investors. When the buying price of the mortgages is determined, the futures transaction is reversed by

I"Since the mortgage inventory is likely to have been financed by short-term flinancing, the spread between the financing interest rate and the mortgage interest rate is presumably favorable to the mortgage bank if such a procedure is followed. If the interest rate spread is not favouble, the mortgage bank may be speculating that mortgage interest rates will fall in the near future, thereby realizing a speculative profit. Of course, in the latter case, the firm would choose not to hedge. 
selling futures. If this price closely reflects the GNMA pass-through market price, the firm will again succeed in protecting its profit from loan origination.

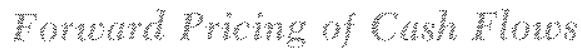

Another use of the mortgage futures market is the forward pricing of expected cash inflows by financial intermediaries. For example, permanent investors, such as savings and loan associations, usually have relatively steady cash inflows, so that fairly accurate projections of these flows over, say, a six-month period, are possible. In addition, the offering rates for funds by these thrift institutions, that is, the rates paid on savings deposits, are relatively fixed over periods of time, which, in effect, results in a de facto commitment by these institutions. Since the price at which they sell these funds (buy mortgages) changes as market interest rates change, and thereby affect their short-1un profits, they may wish to protect themselves from such risk. For these reasons, financial intermediaries may make commitments to buy mortgages at fixed prices several months in advance of their delivery. In so doing, the firm may lock-in the existing margin between its buying rate for funds and the selling rate (buying price of mortgages). Finding such arrangements in the cash market can be difficult. Therefore, the GNMA futures market offers a convenient alternative for locking-in a given yield on a cash How before it is received.

Illustration II presents an example of this type of hedging. Suppose in June a financial intermediary, such as a savings and loan association, forecasts its net cash inflows over the next three nonths at $\$ 1.92$ million and would like to invest these funds in GNMA securities which currently are yielding 8.514 percent. The buying rate for savings and time deposits is expected to average 6 percent and remain unchanged over the period. The savings and loan association views this current profit margin as satisfactory and thus decides to lock-in the 8.514 percent yield. This can be accomplished by buting September GNMA futures contracts. Suppose that by September current mortgage interest rates have fallen to 8 percent. The savings and loan buys Ginnie Mae 8 s in the cash market for 99-21. ${ }^{13}$ The firm completes the hedging transaction by selling 20 September GNMA futures contracts which are assumed to be also trading for

\footnotetext{
19Because of the GNMA 15-day interestmfee servicing delay provision, an 8 percent GNMA yields 8 percent at a price of $99-21 / 32$, assuming a 30 year mortgage prepaid in the twelfth year.
}

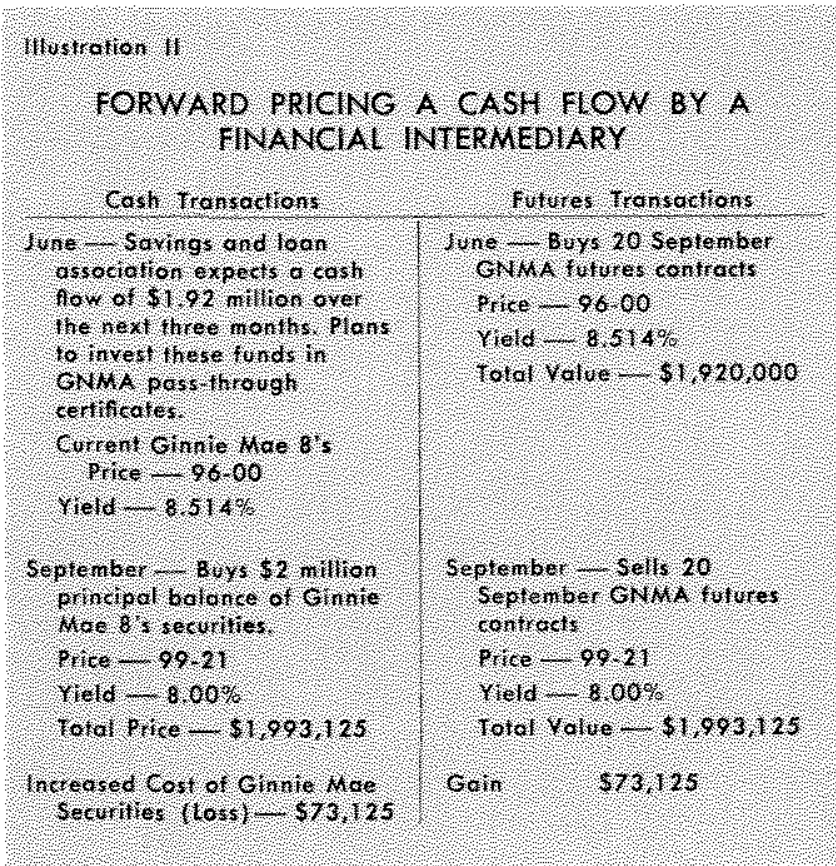

99-21. The cash transactions result in the firm paying $\$ 73,125$ more for the securities than it would have paid in June, while the futures market transactions yield a profit of a like amount. Thus, on balance, the firm will receive the 8.5 percent yield on the $\$ 1.92$ million cash flow.

Although a financial intermediary can lock-in a given yield on a cash flow before it has actually been received, stuch a procedure cannot assure that such profitable opportunities will develop nor can it assure long-term investors that mortgages will be profitably held over their entire life. A problem of some intermediaries, such as savings and loan associations, is the different average length of maturities between its assets (mostly mortgages) and its liabilities (time and savings deposits). Savings and loan associations generally have a shorter average maturity structure in their liabilities than in their assets. Therefore, if interest rates rise unexpectedly over a prolonged period of time, long-term assets must be carried with higher cost funds, that is, higher rates on time and savings deposits, resulting in financial losses to these institutions. ${ }^{14}$ This type of interest rate risk borne by permanent investors cannot be hedged effectively in the GNMA futures market since the movements of rates paid on time and savings deposits are not likely to be very close to movements in GNMA futures prices.

\footnotetext{
I4Such rates are currently constrained by Government regulations, thus forcing a quantity adjustment (amount of funds held at these intermediaries) rather than a price adjustment when yields on alternative market instruments rise signiffcantly above regulated rates.
} 


\section{Speonation}

A futures market can be used both to hedge and to speculate. The hedging firm is one which in the normal course of business takes a cash position in a particular commodity, and wishes to protect its position from adverse price (yield) movements by taking an equal and opposite position in the futures market. The speculator, on the other hand, is willing to assume an open position either in the cash market or in the futures market. In other words, the speculator wishes to take the risk of price (yield) changes motivated by the expectation that price movements will yield him a profit.

Mortgage market participants themselves often have strongly held expectations about the course of future interest rate movements and may believe their projections of future interest rates are better than those implied in current market rates. Thus, participants in the mortgage market who normally take cash positions in mortgages may find the GNMA futures market a convenient tool to carry out speculative decisions.

For example, firms might follow what could be referred to as "selective hedging" strategy. Such a strategy would entail the use of the futures market to hedge transactions when interest rate movements are expected to benefit the firm while leaving its cash positions open (unhedged) when this is expected to benefit the firm. For example, a well-capitalized mortgage company may have an opportunity to originate $\$ 1$ million in loans. The company is reasonably certain that interest rates will fall by the time the loans are closed and ready for delivery to an investor. Thus the company commits itself to make the loans at the current interest rate expecting that it can later sell the loan to a permanent investor at a profit. If, however, the company expected interest rates to rise rather than fall, it could cover that transaction in the futures market, as in Illustration I, avoiding either loss or gain.

Firms using speculative decisions based on forecasts of interest rate movements are likely to be major users of the futures market. They gain to the extent that their expectations are more accurate than those implied in market prices; they lose to the extent that their expectations are less accurate than those implied in the markets.

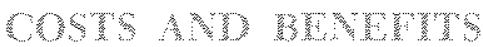

Most of the previous examples illustrate the uses of the mortgage futures market as a means of minimizing the risks associated with interest rate changes. But futures trading involves costs as well as benefits, and these costs must be weighed in order to decide whether or not futures trading should be undertaken.

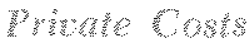

Some costs involved in futures trading to individual firms are obvious and some are hidden. The fee charged by brokers on a round of futures trading is a direct cost while the foregone income from the margin required by brokers is a less obvious cost. Margins are actually earnest money or a security deposit which futures traders must hold with their broker. Margins can be divided into two parts - initial margin, which all buyers and sellers of futures contracts must deposit with their broker - and variation or maintenance margin. This latter type of margin covers daily fluctuations in the value of the contract, thus additional margin will be required if the market value declines sufficiently. On the other hand, if the market value of the contract increases, such increases are credited to the customer's account and may be withdrawn by the customer. In some cases, the initial margin can be held in the form of Treasury bills such that the customer gains interest income, thus reducing the effective cost of futures trading. ${ }^{15}$

Although the hedger avoids interest rate risk with proper hedging, he becomes subject to a new risk, that of a changing relationship between the futures market and cash market yields. This relationship is often known as basis. In the simplified illustrations presented earlier no change in basis was assumed, thus gains and losses in the cash market were exactly offset by the results from futures market transactions. In practice, substantial changes in basis can occur, thus gains and losses in the two markets will not be exactly offsetting. Since the mortgage futures market is based on a specific trading instrument - namely, GNMA pass-through certificates - those markets in which interest rates closely parallel the GNMA market will offer the best possibilities for successful hedging. Changes in basis or spread between yields in the GNMA futures market and other markets must be carefully examined before GNMA futures are used to hedge transactions in other markets. ${ }^{16}$ In practice,

\footnotetext{
1 Noted by David R. Ganis in "CNMA Futures Market Has Advantages, But Not a Way to Make or Take Delivery," Mortgage Banker (January 1976), p. 20.

16See Kenneth M. Plant, "Playing the Futares Market Game," Federal Home Loan Bank Board Journal (November 1975), pp. 16-21, for a discussion of statistical correlations between various yield series and GNMA yields; also see "Hedging in GNMA Mortgage Interest Rate Futures," pp. 44-53, for graphs comparing several interest rate series to GNMA yields.
} 
much of the time and expertise devoted to futures trading will be directed toward analysis of the basis between the GNMA market and the instruments being hedged.

The firmness of a commitment is another consideration in hedging. Commitments thought to be firm have been broken, leaving the hedger open to price level risks. Mortgage production that doesn't materialize as expected, leaves the hedging institution with only its futures position and thus subject to the gains or losses which an open position entails.

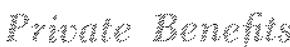

The possible costs of futures trading must be weighed against the benefits which the firm perceives from hedging operations. The primary benefit from hedging operations is the reduction of risk from large losses resulting from major changes in mortgage interest rates. The degree of profit stability afforded by hedging will be evaluated differently by individual firms. Firms in a highly leveraged position may wish the protection offered by hedging certain transactions while other less leveraged firms may be more inclined to take the risks of an unhedged position.

Increased capital leverage is another possible benefit of hedging. Mortgage companies that operate primarily on borrowed funds would seem to benefit most from this aspect. To the extent that the mortgage company operations are hedged and risks reduced, lenders should be more willing to make larger loans, allowing for more intensive use of the company's capital.

The mortgage futures market also gives greater flexibility and reduces search time in carrying out hedging and speculative decisions. Existing practices, as noted earlier, already allow transactions to be hedged by various cash market transactions, but finding other buyers or sellers at the preferred time may be difficult and costly.

\section{bochen}

According to some proponents, social benefits should result from a mortgage futures market, including somewhat lower average mortgage interest rates, slightly lower effective housing prices, and less volatility of mortgage interest rates. These proponents are referring to benefits normally expected from any wellfunctioning market.
A futures market, in general, can be thought of as one in which risk is being traded. In the case of the GNMA futures market, specialization occurs by separating the risk of changing interest rates from the mortgage lending function. In many respects such a separation of price level risk from other business risks is similar to the separation of theft or fire risks from other business risk. These risks are reduced through the purchase of theft and fire insurance. In the case of futures markets, the burden of price level risk is shifted to those who wish to assume such risks. Speculators are willing to assume the risk of losses from price level changes in anticipation of a profit. But in the aggregate the net gains to speculators over the long run is probably near zero, assuming they are no better at anticipating price level movements than hedgers. ${ }^{17}$

A market acts as a focal point where buyers and sellers can meet readily, reducing search costs, increasing market information, and thus increasing efficiency in resource use. A futures market in mortgages, along with the development of secondary mortgage markets, should lead to less segmentation in the mortgage market as local lending rates become more competitive with national rates, and thus result in more efficient allocation of mortgage funds throughout the country. In turn, as mortgage markets become more integrated, the futures market can be used more successfully to hedge risks since interest rates in various markets will tend to move together.

\section{Socing Cogks}

The futures market is not without social costs, for it consumes a portion, although a very small portion, of society's resources - buildings, equipment, paper, labor, etc. But in a free market setting it appears that such costs will be outweighed by the benefits accruing to society. Although the benefits may be sizable from society's viewpoint, individual homebuyers cannot expect to see a significant drop in housing costs.

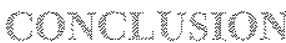

The GNMA mortgage interest rate futures market offers participants a way to separate the risk of interest rate movements from other types of business risk. Institutions can use this market to hedge their cash positions, either actual or expected, against large

17Possibility below zero when commissions and the opportunity cost on margins are taken into account. 
financial losses resulting from adverse movements in mortgage interest rates. Loan originators, such as mortgage banks or savings and loan associations acting as originators, can use this market to avoid interest rate risks when making commitments to either buy or sell mortgages. In so doing, institutions can protect profits accruing from loan origination and servicing. Permanent investors, such as savings and loan associations or insurance companies, can use this market to lock-in the current yield on a cash flow to be received in the future. In addition, this market allows specula- tive transactions on mortgage interest rates to be carried out in a convenient way.

This market will not solve all the problems of the housing industry. However, it is likely to offer sig. nificant benefits including increased market information, less search time, integration of markets and greater specialization of risk bearing. All these add up to greater efficiency in the use of resources, and thus should ultimately benefit home purchasers, savers, and the public at large.

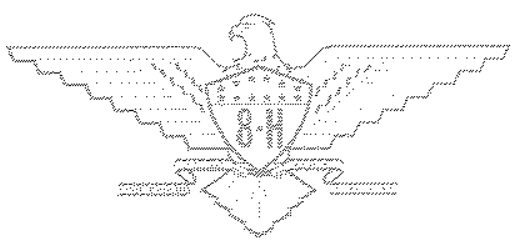

